University of Nebraska - Lincoln

DigitalCommons@University of Nebraska - Lincoln

USDA Wildlife Services - Staff Publications

U.S. Department of Agriculture: Animal and Plant Health Inspection Service

2016

\title{
Bait flavor preference and immunogenicity of ONRAB baits in domestic dogs on the Navajo Nation, Arizona
}

\author{
Are R. Berentsen \\ USDA/APHIS/WS/National Wildlife Research Center \\ Scott Bender \\ Navajo Nation Department of Agriculture \\ Peggy Bender \\ USDA/APHIS/Wildlife Services \\ David Bergman \\ USDA/APHIS/Wildlife Services
}

Amy T. Gilbert

USDA/APHIS/WS/National Wildlife Research Center, Amy.T.Gilbert@aphis.usda.gov

See next page for additional authors

Follow this and additional works at: https://digitalcommons.unl.edu/icwdm_usdanwrc

Part of the Life Sciences Commons

Berentsen, Are R.; Bender, Scott; Bender, Peggy; Bergman, David; Gilbert, Amy T.; Rowland, Hannah M.; and VerCauteren, Kurt C., "Bait flavor preference and immunogenicity of ONRAB baits in domestic dogs on the Navajo Nation, Arizona" (2016). USDA Wildlife Services - Staff Publications. 1859.

https://digitalcommons.unl.edu/icwdm_usdanwrc/1859

This Article is brought to you for free and open access by the U.S. Department of Agriculture: Animal and Plant Health Inspection Service at DigitalCommons@University of Nebraska - Lincoln. It has been accepted for inclusion in USDA Wildlife Services - Staff Publications by an authorized administrator of DigitalCommons@University of Nebraska - Lincoln. 


\section{Authors}

Are R. Berentsen, Scott Bender, Peggy Bender, David Bergman, Amy T. Gilbert, Hannah M. Rowland, and Kurt C. VerCauteren 


\title{
Research
}

\section{Bait flavor preference and immunogenicity of ONRAB baits in domestic dogs on the Navajo Nation, Arizona}

\author{
Are R. Berentsen ${ }^{\mathrm{a}, *}$, Scott Bender ${ }^{\mathrm{b}}$, Peggy Bender ${ }^{\mathrm{c}}$, David Bergman ${ }^{\mathrm{c}}$, Amy T. Gilbert ${ }^{\mathrm{a}}$, \\ Hannah M. Rowland ${ }^{\mathrm{d}, \mathrm{e}}$, Kurt C. VerCauteren ${ }^{\mathrm{a}}$
}

${ }^{a}$ USDA/APHIS/WS/National Wildlife Research Center, Fort Collins, Colorado

${ }^{\mathrm{b}}$ Navajo Nation Department of Agriculture, Navajo Nation, Arizona

${ }^{\mathrm{c}}$ USDA/APHIS/Wildlife Services, Phoenix, Arizona

d Department of Zoology, University of Cambridge, Cambridge, England

${ }^{\mathrm{e}}$ The Institute of Zoology, The Zoological Society of London, London, England

\section{A R T I C L E I N F O}

\section{Article history:}

Received 4 April 2016

Received in revised form

8 July 2016

Accepted 8 August 2016

Available online 18 August 2016

\section{Keywords:}

Canis familiaris

domestic dog

Navajo Nation

ONRAB

oral rabies vaccination

rabies

vaccine

wildlife disease

\begin{abstract}
A B S T R A C T
Rabies is responsible for an estimated 59,000 human deaths worldwide, and domestic dogs are the primary reservoir and vector of the disease. Among some nations, widespread vaccination has led to elimination of rabies in domestic dogs, yet dogs are still susceptible to rabies infection from interactions with wildlife reservoirs. On Tribal lands in the United States, less than $20 \%$ of domestic dogs are vaccinated for rabies, and parenteral vaccination is often unfeasible. Oral rabies vaccination may provide a solution, but a suitable bait flavor and vaccine must be identified. We evaluated 5 bait flavors (bacon, cheese, egg, fish, and sweet) in pairwise flavor-preference trials using placebo Ultralite baits in 26 domestic dogs on the Navajo Nation, Arizona. Each bait flavor was offered a total of 104 times. In all paired comparisons, bacon was more frequently preferred to the alternative. The sweet flavor (the flavor used operationally for oral rabies vaccine (ORV) distribution in Canada) was least preferred. Forty domestic dogs were offered baits containing ONRAB ORV: 14 received the sweet-flavored bait packet and 26 received bacon-flavored baits. Serum was collected from dogs before vaccination and at day 14 and 30 or 37 days after vaccination. Thirty-seven dogs consumed the baits, 2 baits (both sweet flavored) were chewed and spit out, and 1 (sweet flavored) was swallowed without apparent chewing (gulped). Eight dogs had preexisting rabies virus neutralizing antibody (RVNA) titers and 13 naïve dogs failed to seroconvert during the study period. Overall, 27 dogs (67.5\%) showed increased RVNA titers after vaccination, including $1 \mathrm{dog}$ who chewed and spit out the bait and all dogs with positive baseline RVNA titers. Geometric mean titers for all dogs that seroconverted during the study period peaked at day 14 (1.2 IU/ $\mathrm{mL} ; \mathrm{n}=24)$ and decreased slightly by the final sampling day $(0.8 \mathrm{IU} / \mathrm{mL} ; \mathrm{n}=27)$. We conclude that bacon flavor may be a suitable bait flavor for ORV distribution in loosely kept or free-roaming domestic dogs. Seroconversion among dogs who ingested ONRAB-filled baits was variable. Why 13 dogs who consumed ORV baits failed to seroconvert remains unknown. Additional research to improve seroconversion rates in domestic dogs after vaccination with ONRAB is recommended.
\end{abstract}

Published by Elsevier Inc.

\section{Introduction}

Rabies is responsible for an estimated 59,000 human deaths annually (Hampson et al., 2015; Knobel et al., 2005; Meslin et al., 2000), and domestic dogs (Canis familiaris) are the primary

\footnotetext{
* Address for reprint requests and correspondence: Are R. Berentsen, USDA/ APHIS/WS/National Wildlife Research Center, 4101 LaPorte Avenue, Fort Collins, CO 80521, USA. Tel: 970-266-6221; Fax: 970-266-6157.

E-mail address: Are.R.Berentsen@aphis.usda.gov (A.R. Berentsen).
}

terrestrial rabies reservoir and vector globally. Among some developed nations, widespread vaccination of domestic dogs has eliminated rabies virus circulation in dogs (Held et al., 1967). However, even in some areas considered canine rabies free, domestic dogs are still susceptible to infection with variants of rabies carried by wildlife, at risk to infected dogs imported to the area (Castrodale et al., 2008; McQuiston et al., 2008; Windiyaningsih et al., 2004), and populations of feral dogs exist which are inaccessible or not targeted for parenteral vaccination (Meslin et al., 2000; Wandeler and Bingham, 2000). 
One method to increase vaccination rates for domestic dogs that cannot be physically handled may be the distribution of oral rabies vaccine (ORV; Estrada et al., 2001; Perry et al., 1988; Zhang et al., 2008).

In the United States, ORV has been used to vaccinate against rabies in numerous terrestrial wildlife reservoirs including raccoons (Procyon lotor), gray foxes (Urocyon cinereoargenteus), and coyotes (Canis latrans) (Slate et al., 2005, 2009). A 1994 outbreak of canine rabies in domestic dogs and coyotes resulted in aggressive vaccination strategies, including ORV (Sidwa et al., 2005), which ultimately led to the eradication of the domestic dog-coyote variant of rabies from the United States (Slate et al., 2005, 2009; VelascoVilla et al., 2008). It is possible that such applications could be expanded for use in regions where unvaccinated feral dogs are abundant and at risk of infection.

There are over 1.6 million dog bite injuries in the United States every year with the majority occurring in children $<15$ years of age (Quirk, 2012). Hospitalizations due to dog bites among people $<20$ years of age are nearly twice as high for Native American and Alaska Native children than for the general US population (Bjork et al., 2013). In addition, on Tribal Lands in the United States, $<20 \%$ of domestic dogs are vaccinated against rabies or any other disease (Bergman et al., 2008, 2009). During 2013-2015, over 1000 dog bite cases were investigated by the Navajo Nation Animal Control Program with over 900 outpatient and 500 emergency room visits reported to local medical facilities (SB, Navajo Nation Veterinary Program, personal communication). Despite this, there has not been an indigenous case of human rabies in the United States associated with the domestic dog-coyote variant reported since 1994 (Dyer et al., 2014; Petersen and Rupprecht, 2011) and the last reported case of terrestrial rabies on the Navajo Nation was in 1949.

Distribution of ORV baits may provide a viable option for vaccinating free-ranging dogs, but little information exists on whether domestic dogs will ingest ORV baits and, if so, which bait flavor would optimize uptake. Bergman et al. (2008) found that, of 4 commercially produced ORV candidate baits, a fish-flavored coated sachet had the highest bait consumption among baits tested. Berentsen et al. (2014a) found domestic dogs consumed bacon-flavored baits with a similar frequency as a sardine, dog food, or cheese matrix. However, Bergman et al. (2008) used only placebo baits and Berentsen et al (2014a) evaluated only the bait flavor matrix, with no internal vaccine packet. The only ORV currently licensed for use in wildlife in the United States is Raboral V-RG (Merial, Ltd., Athens, GA) which has undergone limited evaluation in domestic dogs. Cliquet et al. (2008) found 12 of 15 naïve dogs survived challenge with rabies virus 28 days after oral vaccination by Raboral V-RG baits. Rupprecht et al. (2005) found that 5 of 6 domestic dogs survived challenge with rabies virus 5 weeks after vaccination by direct instillation into the oral cavity with an experimental recombinant vaccinia rabiesglycoprotein.

In Canada, the ONRAB vaccine (Artemis Technologies) is registered to vaccinate free-ranging striped skunks (Mephitis mephitis) and is currently under evaluation for use in the United States (Slate et al., 2014). Research by Knowles et al. (2009) found 100\% (4/4) of domestic dogs seroconverted after direct instillation of ONRAB vaccine onto the oral cavity, but seroconversion following ingestion of vaccine-filled baits was not evaluated.

Our objectives were to (1) evaluate preferences among 5 flavors of placebo Ultralite baits (Artemis Technologies, Inc., Guelph, Ontario, Canada) by domestic dogs to determine which flavors may be most suitable for ORV delivery to domestic dogs and (2) use the top-performing Ultralite bait flavor from objective 1 to deliver ONRAB ORV to domestic dogs and investigate immune response to vaccination by measuring rabies virus neutralizing antibody (RVNA) titers.

\section{Materials and methods}

We conducted our study at the Navajo Nation Animal Control Facility on the Navajo Nation, Arizona. Study subjects were mixedbreed feral dogs captured by animal control officers or dogs voluntarily surrendered by owners. All dogs were given a physical examination by a licensed veterinarian (Scott Bender) before inclusion in the study. Any dogs showing overt signs of clinical disease (i.e., canine distemper, etc.) or dogs with medical issues requiring extensive treatment were excluded. Dogs were housed at Navajo Nation Animal Control Facility in indoor/outdoor kennels, fed a daily ration of commercial dry dog food, with water available ad libitum. A complete description of the study site and animal care procedures is found in Berentsen et al. (2014a). Vaccination histories for the study subjects were unknown.

The Ultralite bait (Artemis Technologies, Ontario, Canada) used to deliver the ONRAB vaccine consists of a $30 \times 14 \times 10 \mathrm{~mm}(1.18 \times$ $0.55 \times 0.39$ in) elongated blister pack with a waxy external coating. The coating consists of partially hydrogenated vegetable shortening, vegetable oil, food dye, and a food-derived flavoring. Baits used in flavor-preference trials were placebos containing only water. During vaccine trials, each Ultralite bait contained $1.8 \pm 0.1 \mathrm{~mL}$ of ONRAB vaccine (titer of $\geq 10^{9.5}$ cell culture infectious dose $50 \%$ / $\mathrm{mL}$ ). Details on the composition of the bait matrix and vaccine are previously described (Rosatte et al., 2009).

\section{Flavor-preference trials}

We conducted the flavor-preference experiments with 26 dogs (10 males, 16 females) in 2 trials with 12 and 14 dogs in the first and second trials, respectively. Five bait matrix flavors were selected for evaluation (bacon, cheese, sweet, egg, and fish) based on previous research with domestic dogs (Berentsen et al., 2014a; Bergman et al., 2008) and coyotes (Berentsen et al., 2014b). Baits were offered in pairs with each pair combination randomly assigned. Two bait pairs were offered to each dog each day: one pair in the morning before feeding and the second pair 6-8 hours later. Each bait flavor was offered to each dog 4 times with all 10 pair combinations represented for each dog in a balanced randomized block design.

\section{Vaccine trials}

Vaccine-filled baits were offered to 40 dogs ( $16 \mathrm{~m}, 24 \mathrm{f}$ ), 26 (10 $\mathrm{m}, 16 \mathrm{f}$ ) of which were participants in the flavor-preference trial. Fourteen (the first trial subjects from objective 1 plus 2 naïve dogs) received the sweet-flavored bait used operationally for vaccinating free-ranging skunks and raccoons in Canada (Rosatte et al., 2009). Twenty-six dogs (the second trial group from objective 1 plus 12 naïve dogs) received vaccine-filled baits whose flavor was determined by objective 1 . The 14 dogs repurposed from objective 1 received vaccine-filled baits following an approximately 3-month "washout period" following the flavorpreference trials. The remaining 12 dogs were naïve. A single vaccine-filled bait was offered to each dog before feeding of their daily ration. Any bait not consumed within 24 hours was considered a rejection.

Before vaccination and at days 14 and 30 or 37 after vaccination, each dog was anesthetized via intramuscular injection of a $0.5-\mathrm{mL}$ combination of 50-mg Telazol (tiletamine/zolazepam), 40-mg 
ketamine $\mathrm{HCl}$, and 10-mg xylazine, which provided 30 minutes of anesthesia per dog. A blood sample (3-4 mL) was collected via venipuncture of the cephalic or jugular vein. Blood samples were centrifuged and the serum transferred to individual cryovials and frozen at $-20^{\circ} \mathrm{C}$. Samples were shipped to the Rabies Laboratory at Kansas State University (Manhattan, Kansas). Serologic analysis for RVNAs was performed using the rapid fluorescent focus inhibition test (Smith et al. 1996). Titers were converted to IU per mL by comparison with the US Standard Rabies Immune Globulin diluted to 2 IU per mL (SRIG, Laboratory of Standards and Testing, Food and Drug Administration). All dogs with RVNA titers $\geq 0.1 \mathrm{IU} / \mathrm{mL}$ were considered seropositive. Dogs with RVNA titers $<0.1 \mathrm{IU} / \mathrm{mL}$ were considered seronegative.

\section{Data analysis}

\section{Bait preferences}

We assumed that each food type had an unknown desirability score. We therefore calculated the probability that an individual dog chose food type A over B by the size of the difference between their scores. We estimated the relative desirability score for each food type using logistic regression and fitted the probability that the food type presented on the left was chosen to the difference between the scores of the food types offered in the left- and righthand bowls in an implementation of the Bradley and Terry method of paired comparison (Bradley and Terry, 1952):

$\operatorname{logit}\left(P_{\mathrm{j}}\right)=b_{1} * X_{1 \mathrm{j}}+b_{2} * X_{2 \mathrm{j}}+b_{3} * X_{3 \mathrm{j}}+b_{4} * X_{4 \mathrm{j}}+b_{5} * X_{5 \mathrm{j}}$

where:

$P_{\mathrm{j}}=$ probability that the left-hand bait flavor was chosen first in the $\mathrm{j}$-th experiment; coefficient $b_{\mathrm{i}}$ is the relative desirability score for the $\mathrm{i}$-th food type; independent variable $X_{\mathrm{i}}=1$ if the $\mathrm{i}$-th bait flavor is offered on the left; -1 if it is offered on the right; 0 if it is not offered in the $\mathrm{j}$-th experiment.

Not all dogs ate both baits they were offered. In cases where the dog only ate 1 bait, that flavor was regarded as preferred; where none were eaten, the trial was omitted.

The relative sizes of the coefficients gave us a ranking for the food preferences. However, standard logistic regression does not take account of difference in preference between individuals so the standard errors of these coefficients may be underestimated. We used bootstrapping (Efron, 1981), resampling individuals (rather than experiments) to yield 1,000 estimates of the ranking. This allowed us to assign a confidence (or probability) to each of the more plausible rankings while taking individual differences into account.

\section{Serological assays}

Serologic results were summarized using descriptive statistics with geometric mean RVNA titer values.

\section{Results}

\section{Flavor preference}

Each bait flavor was offered a total of 104 times. Bacon flavor was eaten more frequently $(88 / 104 ; 84.6 \%)$, followed by cheese $(85 / 104$; $81.7 \%)$, fish (84/104; 80.7\%), egg (83/104; 79.9\%), and sweet (56/ $104 ; 53.8 \%$ ). One dog did not consume any bait. In all paired comparisons, bacon was more frequently preferred to the alternative, cheese was more frequently preferred to the alternative except bacon; fish was more frequently preferred only to egg and sweet (Table 1).
Table 1

Bait flavor-preferences likelihoods derived from 1000 bootstrap samples

\begin{tabular}{lc}
\hline Ranking & Likelihood (\%) \\
\hline Bacon-cheese-fish-egg-sweet & 46.1 \\
Bacon-cheese-egg-fish-sweet & 40.6 \\
Bacon-egg-cheese-fish-sweet & 7.9 \\
Bacon-fish-cheese-egg-sweet & 3.2 \\
Bacon-egg-fish-cheese-sweet & 1.0 \\
Cheese-bacon-fish-egg-sweet & 0.6 \\
Cheese-bacon-egg-fish-sweet & 0.4 \\
Bacon-fish-egg-cheese-sweet & 0.2 \\
\hline
\end{tabular}

\section{Serology}

Twenty-six dogs ( $9 \mathrm{~m}, 17 \mathrm{f}$ ) were offered bacon-flavored vaccine baits (Table 2). All baits were consumed. Three dogs had preexisting antibody titers, and all 3 dogs showed increased RVNA titers following bait consumption. Nine naïve dogs (39\%) failed to seroconvert within the study period (30-37 days), although all 9 consumed a bait. Geometric mean RVNA titers for naïve dogs that seroconverted by the end of the trial peaked at day $14(0.9 \mathrm{IU} / \mathrm{mL}$; range: $0.1-5.0, \mathrm{n}=12$ ) and decreased to $0.7 \mathrm{IU} / \mathrm{mL}$ (range: $0.1-2.8$, $\mathrm{n}=14$ ) by day 30 or 37 after vaccination (Figure).

Fourteen dogs $(7 \mathrm{~m}, 7 \mathrm{f})$ were offered the sweet-flavored vaccine-filled bait: 11 baits were consumed, 2 were chewed and spit out, and 1 was swallowed without apparent chewing (i.e., gulped; Table 2). Five dogs had preexisting antibody titers, but only 3 of 5 dogs showed increased antibody titer values after vaccination. Of 7 naïve dogs who consumed baits, 3 (43\%) failed to seroconvert by day 30 after vaccination. The dog that gulped the bait had a preexisting titer of $1.0 \mathrm{IU} / \mathrm{mL}$, which decreased to 0.3 $\mathrm{IU} / \mathrm{mL}$ after vaccination. Of the 2 dogs that chewed and spit out the bait, 1 achieved a maximum titer of $0.1 \mathrm{IU} / \mathrm{mL}$ by the final sampling day and the second remained seronegative. Two baits were described as "leaking" when offered, although both baits were consumed and both dogs seroconverted. The amount of potential vaccine spillage was not recorded. Geometric mean titer values for the 5 naïve dogs who seroconverted by day 30 (including the dog that chewed and spit out the bait) peaked at day $14(0.4 \mathrm{IU} / \mathrm{mL}$; range $0.1-4.2 \mathrm{IU} / \mathrm{mL}, \mathrm{n}=4)$ and decreased to $0.2 \mathrm{IU} / \mathrm{mL}$ (range: $0.1-2.3 \mathrm{IU} / \mathrm{mL}, \mathrm{n}=5$ ) by the final sampling period (Figure).

\section{Discussion}

It is interesting to note that sweet-flavored baits were consumed least by dogs, despite research that suggests canids tend to prefer sweet-flavored items (Berentsen et al., 2006; Ferrell, 1984; Mason and McConnell, 1997; Thombre, 2004). However, our results relative to preference of sweet-flavored baits are consistent with previous flavor-preference research using Ultralite bait matrix blocks in domestic dogs (Berentsen et al., 2014a) and placebo ONRAB baits in coyotes (Berentsen et al., 2014b).

Overall, 26 dogs (67.5\%) showed increased RVNA titers after vaccination, including dogs with positive baseline RVNA titers and 1 dog who chewed but spit out the bait. Why 13 dogs who consumed baits failed to seroconvert after vaccination remains unknown, but similar results were found by Cliquet et al. (2008) where 10 of 15 seronegative dogs failed to seroconvert after vaccination. However, it is important to note that Cliquet et al. (2008) used different RVNA titer thresholds as well as serologic methods (FAVN vs. rapid fluorescent focus inhibition test) than in this study. Furthermore, failure to seroconvert may not necessarily indicate lack of protection. Cliquet et al. (2008) found that although 10 of 15 dogs failed to 
Table 2

Consumption and RVNA titer values

\begin{tabular}{|c|c|c|c|c|c|}
\hline \multirow[t]{2}{*}{ ID } & \multirow[t]{2}{*}{ Bait type } & \multirow[t]{2}{*}{ Bait fate } & \multicolumn{3}{|c|}{ Virus neutralizing antibody titer $(\mathrm{IU} / \mathrm{mL})^{\mathrm{a}}$} \\
\hline & & & Prevaccination & Day 14 & Day $30 / 37$ \\
\hline $11 \mathrm{~F}$ & Sweet & Consumed & $<0.1$ & $<0.1$ & $<0.1$ \\
\hline $13 \mathrm{~F}$ & Sweet & Consumed & $<0.1$ & $<0.1$ & $<0.1$ \\
\hline $14 \mathrm{M}$ & Sweet & Consumed & $<0.1$ & $<0.1$ & $<0.1$ \\
\hline $2 \mathrm{M}$ & Sweet & Consumed & $<0.1$ & 0.1 & 0.1 \\
\hline $12 \mathrm{M}$ & Sweet & Consumed & $<0.1$ & 0.1 & 0.1 \\
\hline $8 \mathrm{~F}$ & Sweet & Consumed & 0.3 & 0.2 & 0.3 \\
\hline $9 \mathrm{~F}$ & Sweet & Consumed & 0.6 & 0.9 & 0.6 \\
\hline $4 \mathrm{~F}$ & Sweet & Consumed & 2.3 & 15.5 & 13.0 \\
\hline $3 \mathrm{M}$ & Sweet & Consumed & 27.0 & 34.0 & 22.0 \\
\hline $1 \mathrm{M}$ & Sweet & Gulped & 1.0 & 0.3 & 0.3 \\
\hline $6 \mathrm{M}$ & Sweet & Leaking sachet/consumed & $<0.1$ & 0.9 & 0.3 \\
\hline $5 \mathrm{M}$ & Sweet & Leaking sachet/consumed & $<0.1$ & 4.2 & 2.3 \\
\hline $7 \mathrm{~F}$ & Sweet & Chewed, spit out & $<0.1$ & $<0.1$ & 0.1 \\
\hline $10 \mathrm{~F}$ & Sweet & Chewed, spit out & $<0.1$ & $<0.1$ & $<0.1$ \\
\hline $21 \mathrm{M}$ & Bacon & Consumed & $<0.1$ & $<0.1$ & $<0.1$ \\
\hline $23 \mathrm{M}$ & Bacon & Consumed & $<0.1$ & $<0.1$ & $<0.1$ \\
\hline $24 \mathrm{~F}$ & Bacon & Consumed & $<0.1$ & $<0.1$ & $<0.1$ \\
\hline $28 \mathrm{~F}$ & Bacon & Consumed & $<0.1$ & $<0.1$ & $<0.1$ \\
\hline $29 \mathrm{~F}$ & Bacon & Consumed & $<0.1$ & $<0.1$ & $<0.1^{\mathrm{b}}$ \\
\hline $32 \mathrm{M}$ & Bacon & Consumed & $<0.1$ & $<0.1$ & $<0.1^{\mathrm{b}}$ \\
\hline $35 \mathrm{~F}$ & Bacon & Consumed & $<0.1$ & $<0.1$ & $<0.1^{\mathrm{b}}$ \\
\hline $37 \mathrm{~F}$ & Bacon & Consumed & $<0.1$ & $<0.1$ & $<0.1^{\mathrm{b}}$ \\
\hline $40 \mathrm{M}$ & Bacon & Consumed & $<0.1$ & $<0.1$ & $<0.1^{\mathrm{b}}$ \\
\hline $20 \mathrm{~F}$ & Bacon & Consumed & $<0.1$ & $<0.1$ & 0.2 \\
\hline $25 \mathrm{M}$ & Bacon & Consumed & $<0.1$ & $<0.1$ & 2.5 \\
\hline $18 \mathrm{~F}$ & Bacon & Consumed & $<0.1$ & 0.1 & 0.1 \\
\hline $22 \mathrm{~F}$ & Bacon & Consumed & $<0.1$ & 0.1 & 0.3 \\
\hline $19 \mathrm{~F}$ & Bacon & Consumed & $<0.1$ & 0.3 & 0.7 \\
\hline $16 \mathrm{~F}$ & Bacon & Consumed & $<0.1$ & 2.2 & 1.1 \\
\hline $15 \mathrm{~F}$ & Bacon & Consumed & $<0.1$ & 0.7 & 0.8 \\
\hline $26 \mathrm{~F}$ & Bacon & Consumed & $<0.1$ & 1.0 & 2.2 \\
\hline $27 \mathrm{~F}$ & Bacon & Consumed & 0.5 & $>15.0$ & $>15.0$ \\
\hline $17 \mathrm{M}$ & Bacon & Consumed & 0.6 & 6.6 & 8.6 \\
\hline $36 \mathrm{~F}$ & Bacon & Consumed & $<0.1$ & 0.5 & $0.1^{\mathrm{b}}$ \\
\hline $30 \mathrm{~F}$ & Bacon & Consumed & $<0.1$ & 4.3 & $2.4^{\mathrm{b}}$ \\
\hline $34 \mathrm{~F}$ & Bacon & Consumed & $<0.1$ & 5.0 & $2.8^{\mathrm{b}}$ \\
\hline $33 \mathrm{M}$ & Bacon & Consumed & $<0.1$ & 1.7 & $1.0^{\mathrm{b}}$ \\
\hline $31 \mathrm{M}$ & Bacon & Consumed & $<0.1$ & 1.7 & $1.1^{\mathrm{b}}$ \\
\hline $39 M$ & Bacon & Consumed & $<0.1$ & 2.0 & $0.5^{\mathrm{b}}$ \\
\hline $38 \mathrm{~F}$ & Bacon & Consumed & 0.2 & 1.5 & $0.6^{\mathrm{b}}$ \\
\hline
\end{tabular}

RVNA, rabies virus neutralizing antibody.

a Levels $<0.1 \mathrm{IU} / \mathrm{mL}$ were considered negative (0).

b Sampled on day 37.

reach the RVNA titer cutoff established to define seroconversion, 12 of 15 dogs survived challenge. Whether this phenomenon is a result of the RVNA threshold used to establish seroconversion in the Cliquet et al. (2008) study is unknown.

Given the results of Knowles et al. (2009) where all dogs survived challenge following direct instillation of $1.8-\mathrm{mL}$ vaccine, it is unlikely that the vaccine volume contained within the Ultralite bait $(1.8 \mathrm{~mL})$ was insufficient to stimulate an immune response in all dogs. It is possible, however, that individual chewing behavior before swallowing bait was insufficient to allow adequate contact with the buccal mucosa required for vaccine absorption. It is also possible but unlikely that given more time, the nonconverters may have seroconverted, as Aubert (1992) suggested peak immune response is achieved in dogs 31 days after vaccination. In contrast, Sattler et al. (2009) suggested optimal timing for detection of RVNA in wildlife species is approximately 6 weeks after vaccination.

Our results suggest high variability in immune response among individual dogs, similar to results found by Aubert (1992) and Cliquet et al. (2008). It is also interesting to note that while all bacon-flavored vaccine-filled baits were consumed, 2 of the sweetflavored baits were spit out. Future research including direct instillation of vaccine into the oral cavity to evaluate RVNA titer response is warranted, as may be experiments including a challenge with rabies virus after vaccination to evaluate vaccine efficacy.

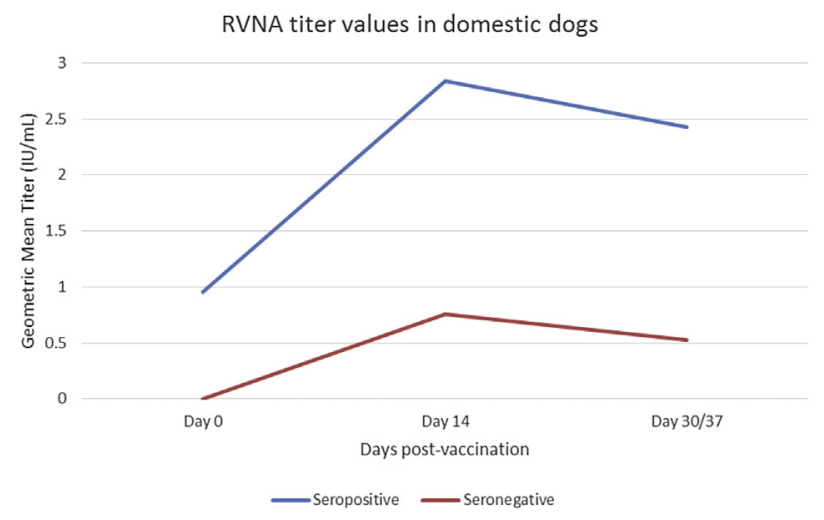

Figure. Geometric mean RVNA titer values of dogs seropositive and seronegative before vaccination. RVNA, rabies virus neutralizing antibody. 


\section{Acknowledgments}

Funding was provided by the National Rabies Management Program. The authors gratefully acknowledge the assistance of the Navajo Nation Animal Control Program and Navajo Nation Fish and Wildlife in providing the animals in this vaccine study and allowing the use of their facilities for the housing of the dogs for the duration of this study.

\section{Ethical considerations}

This research was approved by the USDA National Wildlife Research Center Institutional Animal Care and Use Committee under research protocol QA-2128.

\section{Conflict of interest}

The authors declare no conflict of interest. The idea for the article was conceived by Are R. Berentsen, Scott Bender, David Bergman, and Kurt C. VerCauteren. The experiments were designed by Are R. Berentsen, Scott Bender, and Kurt C. VerCauteren. The experiments were performed by Are R. Berentsen, Scott Bender, and Peggy Bender. The data were analyzed by Are R. Berentsen and Hannah M. Rowland. The article was written by Are R. Berentsen, Amy T. Gilbert, Hannah M. Rowland, and Kurt C. VerCauteren.

\section{References}

Aubert, M.F.A., 1992. Practical significance of rabies antibodies in cats and dogs. Rev. Sci. Tech. Off. Int. Epiz. 11, 735-760.

Berentsen, A.R., Bender, S., Bender, P., VerCauteren, K.C., Bergman, D., 2014a. Preference among seven bait flavors delivered to domestic dogs in Arizona: implications for oral rabies vaccination on the Navajo Nation. J. Vet. Behav.: Clin. Appl. Res. 9, 169-171.

Berentsen, A.R., Brummer, S.P., Young, J.K., VerCauteren, K.C., 2014b. Evaluation of six ONRAB ${ }^{\circledR}$ Ultralite bait flavor matrices delivered to coyotes (Canis latrans): implications for oral rabies vaccination. J. Vet. Behav.: Clin. Appl. Res. 9, 258261.

Berentsen, A.R., Schmidt, R.H., Timm, R.M., 2006. Repeated exposure of coyotes to the Coyote Lure Operative Device. Wildl. Soc. Bull. 34, 809-814.

Bergman, D.L., Breck, S.W., Bender, S.C., 2009., Dogs Gone Wild: Feral Dog Damage in the United States. Proc. Wildlife Damage Manage. Conf. 13, 177-183.

Bergman, D., Bender, S., Wenning, K., Slate, D., Rupprecht, C., Heuser, C., DeLiberto, T., 2008. Bait acceptability for delivery of oral rabies vaccine to freeranging dogs on the Navajo and Hopi Nations. Dev. Biologicals 131, 145-150.

Bjork, A., Homan, R.C., Callinan, L.S., Hennessy, T.W., Cheek, J.E., McQuiston, J.H., 2013. Dog bite injuries among American Indian and Alaska Native Children. J. Pediatr. 162, 1270-1275.

Bradley, R.A., Terry, M.E., 1952. Rank analysis of incomplete block designs: 1. the method of paired comparisons. Biometrika 39, 324.

Castrodale, L., Walker, V., Baldwin, J., Hofmann, J., Hanlon, C., 2008. Rabies in a puppy imported from India to the USA, March 2007. Zoonoses Public Hlth. 55, 427-430.

Cliquet, F., Barrat, J., Guiot, A.L., Caël, N., Boutrand, S., Maki, J., Schumacher, C.L., 2008. Efficacy and bait acceptance of vaccinia vectored rabies glycoprotein vaccine in captive foxes (Vulpes vulpes), raccoon dogs (Nyctereutes procyonoides) and dogs (Canis familiaris). Vaccine 26, 4627-4638.

Dyer, J.L., Yager, P., Orciari, L., Greenberg, L., Wallace, R., Hanlon, C.A., Blanton, J.D., 2014. Rabies surveillance in the United States during 2013. J. Amer. Vet. Med. Assoc. 245, 1111-1123.

Efron, B., 1981. Nonparametric estimates of standard error: the jackknife, the bootstrap and other methods. Biometrika 68, 589-599.

Estrada, R., Vos, A., De Leon, R., Mueller, T., 2001. Field trial with oral vaccination of dogs against rabies in the Philippines. BMC Infect. Dis 1, 23.

Ferrell, F., 1984. Preference for sugars and nonnutritive sweeteners in young beagles. Neurosci. Biobehav. Rev. 8, 199e203.
Hampson, K., Coudeville, L., Lembo, T., Sambo, M., Kieffer, A., Attlan, M., Barrat, J., Blanton, J.D., Briggs, D.J., Cleaveland, S., Costa, P., Freuling, C.M., Hiby, E., Knopf, L., Leanes, F., Meslin, F.-X., Metlin, A., Miranda, M.E., Müller, T., Nel, L.H., Recuence, S., Rupprecth, C.E., Schumacher, C., Taylor, L., Vigilato, M.A.N. Zinsstag, J., Dushoff, J., on behalf the Global Alliance for Rabies Control Partners for Rabies Prevention, 2015. Estimating the global burden of endemic canine rabies. PLoS Negl. Trop. Dis. 9, e0003709.

Held, J.R., Tierkel, E.S., Steele, J.H., 1967. Rabies in man and animals in the United States, 1946-1965. Pub. Health Rep. 82, 1009-1018.

Knobel, D.L., Cleaveland, S., Coleman, P.G., Fèvre, E.M., Meltzer, M.I., Miranda, M.D.G., Shaw, A., Zinsstag, J., Meslin, F.-X., 2005. Re-evaluating the burden of rabies in Africa and Asia. B. World Health Organ. 83, 360-368.

Knowles, M.K., Nadin-Davis, S.A., Shee, M., Rosatte, R., Mueller, R., Beresford, A., 2009. Safety studies on an adenovirus recombinant vaccine for rabies (AdRG1.3ONRAB $^{\circledR}$ ) in target and non-target species. Vaccine 27, 6619-6626.

Mason, J.R., McConnell, J.E., 1997. Hedonic responses of coyotes to 15 aqueous taste solutions. J. Wildl. Res. 2, 21-24.

McQuiston, J.H., Wilson, T., Harris, S., Bacon, R.M., Shapiro, S., Trevino, I., Sinclair, J., Galland, G., Marano, N., 2008. Importation of dogs into the United States: risks from rabies and other zoonotic diseases. Zoonoses Public Hlth. $55,421-426$.

Meslin, F.X., Miles, M.A., Vexenat, J.A., Gemmell, M.A., 2000. Zoonoses control in dogs. In: Macpherson, C.N.L., Meslin, F.-X., Wandeler, A.I. (Eds.), Dogs, Zoonoses and Public Health. CABI, New York, pp. 333-372.

Perry, B.D., Brooks, R., Foggin, C.M., Bleakley, J., Johnston, D.H., Hill, F.W., 1988 A baiting system suitable for the delivery of oral rabies vaccine to dog populations in Zimbabwe. Vet. Rec. 123, 76-79.

Petersen, B.W., Rupprecht, C.E., 2011. Human Rabies Epidemiology and Diagnosis. INTECH Open Access Publisher, Rijeka, Croatia.

Quirk, J.T., 2012. Non-fatal dog bite injuries in the USA, 2005-2009. Public Health 126, 300-302.

Rosatte, R.C., Donovan, D., Davies, J.C., Allan, M., Bachmann, P., Stevenson, B., Sobey, K., Brown, L., Silver, A., Bennett, K., Buchanan, T., Bruce, L., Gibson, M., Beresford, A., Beath, A., Fehlner-Gardiner, C., Lawson, K., 2009. Aerial distribution of ONRAB baits as a tactic to control rabies in raccoons and striped skunks in Ontario, Canada. J. Wildlife Dis. 45, 363-374.

Rupprecht, C.E., Hanlon, C.A., Blanton, J., Manangan, J., Morrill, P., Murphy, S., Niezgoda, M., Orciari, L.A., Schumacher, C.L., Dietzschold, B., 2005. Oral vaccination of dogs with recombinant rabies virus vaccines. Virus Res. 111, 101-105.

Sattler, A.C., Krogwold, R.A., Wittum, T.E., Rupprecht, C.E., Algeo, T.P., Slate, D. Smith, K.A., Hale, R.L., Nohrenberg, G.A., Lovell, C.D., Niezgoda, M., Montoney, A.J., Slemons, R.D., 2009. Influence of oral rabies vaccine bait density on rabies seroprevalence in wild raccoons. Vaccine 27, 7187-7193.

Sidwa, T.J., Wilson, P.J., Moore, G.M., Oertli, E.H., Hicks, B.N., Rhode, R.E., Johnston, D.H., 2005. Evaluation of oral rabies vaccination programs for control of rabies epizootics in coyotes and gray foxes: 1995-2003. J. Amer. Vet. Med. Assoc. 227, 785-792.

Slate, D., Algeo, T.P., Nelson, K.M., Chipman, R.B., Donovan, D., Blanton, J.D., Niezgoda, M., Rupprecht, C.E., 2009. Oral rabies vaccination in North America: opportunities, complexities, and challenges. PLoS Neglect. Trop. D. 3, e549.

Slate, D., Chipman, R.B., Algeo, T.P., Mills, S.A., Nelson, K.M., Croson, C.K., Dubovi, E.J, VerCauteren, K., Renshaw, R.W., Atwood, T., Johnson, S., Rupprecht, C.E., 2014. Safety and immunogenicity of Ontario rabies vaccine bait (ONRAB) in the first US field trial in raccoons (Procyon lotor). J. Wildlife Dis. 50, 582-595.

Slate, D., Rupprecht, C.E., Rooney, J.A., Donovan, D., Lein, D.H., Chipman, R.B., 2005. Status of oral rabies vaccination in the United States. Virus Res. 111, 68-76.

Smith, J.S., Yager, P.A., Baer, G.M., 1996. A rapid fluorescent focus inhibition test (RFFIT) for determining rabies virus-neutralizing antibody. In: Meslin, F.X., Kaplan, M.M., Koprowski, H. (Eds.), Laboratory Techniques in Rabies, 4th ed. World Health Organization, Geneva, Switzerland, pp. 181-190.

Thombre, A.G., 2004. Oral delivery of medications to companion animals: palatability considerations. Adv. Drug Deliver. Rev. 56, 1399-1413.

Velasco-Villa, S.R., Reeder, S.A., Orciari, L.A., Yager, P.A., Franka, R., Blanton, J.D., Zuckero, L., Hunt, P., Oertli, E.H., Robinson, L.E., Rupprecht, C.E., 2008. Enzootic rabies elimination from dogs and reemergence in wild terrestrial carnivores, United States. Emerg. Infect. Dis. 14, 1849-1854.

Wandeler, A.I., Bingham, J., 2000. Dogs and rabies. In: Macpherson, C.N.L., Meslin, F.X., Wandeler, A.I. (Eds.), Dogs, Zoonoses and Public Health. CABI, New York, pp. 63-90.

Windiyaningsih, C., Wilde, H., Meslin, F.X., Suroso, T., Widarso, H.S., 2004. The rabies epidemic on Flores Island, Indonesia (1998-2003). J. Med. Assoc. Thailand 87, 1389-1393.

Zhang, S., Kui, Y., Fooks, A.R., Zhang, F., Hu, R., 2008. Oral vaccination of dogs (Canis familiaris) with baits containing the recombinant rabies-canine adenovirus type-2 vaccine confers long-lasting immunity against rabies. Vaccine 26, 345350. 